\title{
The Youth Olympic Games and a new awakening for sports and exercise medicine
}

\author{
Kathrin Steffen, ${ }^{1,2}$ Lars Engebretsen ${ }^{1,2}$
}

'When can I return to sport?' and 'How can I get active, fit and healthy faster?' Questions like these from the top athlete or from a passionate recreational individual require the clinician to go beyond the diagnosis and to a functional capacity assessment in order to fully understand how the diagnosis has an effect on the patient's well being. Is our reductionist thinking preventing us from using sports and exercise medicine in preventing and managing diseases? Is a 'sports and exercise medicine specialty' part of the answer to these concerns? Please read Gordon Matheson and coworker's viewpoint on this issue. ${ }^{1}$ If the authors have a point, the new specialty 'Sports and Exercise Medicine' as introduced in countries like Great Britain, Australia and New Zealand have their work cut out for them. The IPHP (British Journal of Sports Medicine Injury Prevention and Health Protection) is filled with good reasons for a concerted approach to use sports medicine and exercise as a tool to improve the individual's health, and we will need a coordinated approach to succeed! The Youth Olympic Games, with its cultural and educational emphasis, is one of the International Olympic Committee's approaches to showcase high-level sports as a catalyst for improving the health of the youth.

In August 2010, the first Youth Olympic Games (YOG) for elite summer sport athletes were held in Singapore. The nature of the Games venues provided challenges to the organisation of medical coverage for the 14-18-year old participants and their staff. The paper of Chia and coworkers ${ }^{2}$ describes the planning and delivery of medical services during the Singapore-YOG. Their experiences clearly will help the

${ }^{1}$ Oslo Sports Trauma Research Center, Department of Sports Medicine, Norwegian School of Sports Sciences, Oslo, Norway

2Medical \& Scientific Department, International Olympic Committee, Lausanne, Switzerland

Correspondence to Kathrin Steffen, Oslo Sports Trauma Research Center, Department of Sports Medicine, Norwegian School of Sport Sciences, PO 4014 Ullevål Stadion, Oslo 806, Norway;

kathrin.steffen@nih.no organising committee in Innsbruck, when the next generation of future Olympic winter sports athletes will be gathered during the Youth Olympic Winter Games in Austria, in January 2012. This issue of the British Journal of Sports Medicine - Injury Prevention and Health Protection is dedicated to these young athletes.

A recent review of the literature on injury risk among young elite athletes preparing themselves for sports in the Summer Youth Olympic Games showed that apart from football, little knowledge was available. ${ }^{3}$ In winter sports, even fewer data on injury risk are published on this age group. The Sport Injury Prevention Research Centre at the University of Calgary represents a positive initiative. Having the strong tradition of ice hockey in Canada and access to thousands of Junior hockey players, they have focused on the young players' health for many years. Some of their recent research have shown that the risk for concussion injuries is three times higher for players playing in a league in which body checking is permitted compared with playing in a league in which body checking is not permitted. ${ }^{4}$ These findings have led to much debate in North America, and there are on-going evaluations of the bodychecking rules for young athletes. Enjoy the latest study from the Calgary-group on young elite ice hockey players, and their injury risk associated with team performance and penalty minutes. ${ }^{5}$ Systematic injury surveillance on young elite athletes, as it will be initiated in Innsbruck, will allow monitoring injury trends over time to identify high-risk sports and ensure new knowledge on injury trends to form the basis for further research on injury risk factors, mechanisms and in the final step, on injury prevention initiatives.

We still remember the Olympics in Vancouverwell. Fantastic Games! Attractive TV pictures were broadcasted all over the world. Happy athletes, spectacular competitions, fascinating speed elements, but also disappointments when the personal goal or medal was not reached. Among the negative events were many injuries, which are still too many for our liking! 6
Three studies from the Oslo Sports Trauma Research Center directly address some of the identified high-risk sports. Findings from injury videos and interviews from the Vancouver Olympics and various World Cup competitions describe and analyse the complexity of events leading up to anterior cruciate ligament injuries among World Class alpine skiers ${ }^{7}$ as well as injury incidences and mechanisms among snowboard and ski cross athletes. ${ }^{89}$ Their findings will enable the athletes to prepare better, so that technical and inappropriate tactical choices through the runs get reduced.

You may have followed the FIS (International Ski Federation) discussions on equipment changes, such as longer skis, in alpine skiing. One other hot topic in injury prevention, and not only in skiing safety, is the helmet. McIntosh and his consensus group on 'sports helmet safety' strongly advocate the development of appropriate helmet standards, which address the need for improved helmets in high-level competition compared with helmets for recreational athletes. ${ }^{10}$

And finally: implementation. Though many well-designed intervention studies have been published in the peer-reviewed sports medicine literature, showing that injury risk can be reduced, Caroline Finch in her latest paper, is asking herself, why do sports injuries still happen? Read the editors' choice! ${ }^{11}$ There, Finch has at least three possible answers to this question: there might be (1) a dissemination failure where the results (the effective intervention) have not reached the target audience, (2) a translation/adoption failure where the relevant information reached the key persons (eg, coaches and players), but is not understood by them and (3) a research relevance failure where the research findings are not directly relevant to the realworld scenario!

Good luck in Innsbruck!

\section{Competing interests None.}

Provenance and peer review Not commissioned; externally peer reviewed.

Received 7 October 2011

Accepted 7 October 2011

Br J Sports Med 2011;45:1251-1252.

doi:10.1136/bjsports-2011-090658

\section{REFERENCES}

1. Matheson G0, Klügl M, Dvorak J, et al. Responsibility of sport and exercise medicine in preventing and managing chronic disease: applying our knowledge and skill is overdue. Br J Sports Med 2011;45:1272-82.

2. Chia JK, Tay KB, Suresh P, et al. Medical care delivery at the Inaugural Youth Olympic Games Singapore 2010. Br J Sports Med 2011;45:1283-88. 
3. Steffen K, Engebretsen L. More data needed on injury risk among young elite athletes. $\mathrm{Br} J$ Sports Med 2010;44:485-9.

4. Emery CA, Kang J, Shrier I, et al. Risk of injury associated with body checking among youth ice hockey players. JAMA 2010;303:2265-72.

5. Emery CA, Kang J, Schneider, KJ, et al. Risk of injury and concussion associated with team performance and penalty minutes in competitive youth ice hockey. Br J Sports Med 2011;45:1289-93.

6. Engebretsen L, Steffen K, Alonso JM, et al. Sports injuries and illnesses during the
Winter Olympic Games 2010. Br J Sports Med 2010; 44:772-80.

7. Bere T, Flørenes T, Krosshaug T, et al. Events leading to anterior cruciate ligament injury in World Cup alpine skiing: a systematic video analysis of 20 cases. Br J Sports Med 2011;45:1294-1302.

8. Steenstrup S, Bere T, Flørenes T, et al. Injury incidence in qualification runs versus final runs in FIS World Cup snowboard cross and ski cross. Br J Sports Med 2011;45:1310-14.

9. Bakken A, Bere T, Bahr R, et al. Mechanisms of injuries in World Class Snowboard cross: a systematic video analysis of 19 cases. Br J Sports Med 2011:45:1315-22.

10. McIntosh A, Andersen TE, Bahr R, et al. Sports helmets now and in the future: summary of the Symposium at the 2011 IOC World Conference on Prevention of Injury \& IIIness in Sport. Br J Sports Med 2011;45:1258-65.

11. Finch CF. No longer lost in translation: the art and science of sports injury prevention implementation research. Br J Sports Med 2011;22; Published Online First: 22 June 2011 doi:10.1136/bjsports-2011090230. 